\title{
Studies on Lipoprotein and Adrenal Steroidogenesis : I. Roles of Low Density Lipoprotein- and High Density Lipoprotein- Cholesterol in Steroid Production in Cultured Human Adrenocortical Cells
}

\author{
Masayoshi HigashiJima, Hajime NAWATA, Ken-IChi KATO \\ AND HIROSHI IBAYASHI
}

\begin{abstract}
Third Department of Internal Medicine, Faculty of Medicine, Kyushu University, Fukuoka 812, Japan
\end{abstract}

\begin{abstract}
The roles of human low density lipoprotein (LDL)- cholesterol and high density lipoprotein (HDL)- cholesterol on adrenal steroidogenesis were investigated using cultured human adult and fetal adrenocortical cells and the findings were then compared to those obtained with bovine adrenocortical cells.

The secretion of cortisol in both human and bovine adrenocortical cells was dose-dependently increased by the administration of LDL- or HDLcholesterol in the presence of adrenocorticotropin (ACTH). LDL-cholesterol was utilized to a greater extent than HDL-cholesterol in both human and bovine adrenal steroidogenesis in the presence of ACTH. Exogenous lipoproteinderived cholesterol was less utilized in human adrenal steroidogenesis than in bovine adrenal steroidogenesis, compared to the endogenous cholesterol.

An increase in the secretion of cortisol and dehydroepi androsterone sulfate (DHEA-S) continued for the 5-day culture period, in the presence of lipoprotein cholesterol and ACTH in both human adult and fetal adrenocortical cells. The secretion of aldosterone increased on the first day of the culture period, then gradually decreased for the 5-day culture period in human adult adrenocortical cells, but not in human fetal adrenocortical cells in the presence of lipoprotein cholesterol and ACTH.

These findings demonstrate that exogenous cholesterol utilized in the biosynthesis of steroids is mainly from LDL-cholesterol in both human adult and fetal adrenals and bovine adrenal and the proportion of cholesterol synthesized de novo is significantly larger in the human adult adrenal than in the bovine adrenal.
\end{abstract}

Cholesterol is synthesized de novo from acetate in the adrenals and is utilized for adrenal steroidogenesis (Srere et al., 1948). Borkowski et al. (1967) suggested the importance of the role of plasma cholesterol in adrenal steroidogenesis. The uptake of cholesterol from the blood into the adrenals

Received August 27, 1986 is stimulated by ACTH (Dexter et al., 1970). Studies on lipoprotein metabolism have shown that HDL-cholesterol in rats is preferably utilized for adrenal steroidogenesis (Gwynne et al., 1976; Gwynne and Hess, 1980; Andersen and Dietschy, 1978), while LDL-cholesterol is utilized in mice (Faust et al., 1977; Kovanen et al., 1980), bovine (Kovanen et al., 1979a, 1979b) and human 
fetuses (Carr et al., 1980a, 1980b). Brown et al. (1979) identified the LDL receptor on the adrenocortical cell membrane by which cholesterol is supplied to the adrenocortical cells.

As there is no report on the role of plasma lipoprotein cholesterol in human adult adrenal steroidogenesis, we carried out the studies on the role of LDL- and HDLcholesterol in the human adrenal steroidogenesis in cultured human adult and fetal adrenocortical cells and compared the findings in bovine adrenocortical cells.

\section{Materials and Methods}

\section{Materials}

Fetal calf serum (FCS) and collagenase (type 1) were obtained from Gibco-Biocult (Grand Island, NY) and Sigma Chemical Co. (St. Louis, MO). Synthetic $\alpha^{1-18}$ ACTH was from Shionogi Co. (Osaka, Japan). Plastic culture dishes were from Falcon Plastics (Oxnard, CA). Antidehydroepiandrosterone sulfate (DHEA-S) antibody was kindly supplied by Dr. H. Sekihara, Tokyo University. $\quad\left[7^{-3} \mathrm{H}\right]$ DHEA-S $(22.1 \mathrm{Ci} /$ mmol) was purchased from New England Nuclear Corp. (Boston, MA). Human adult adrenals were surgically removed from eleven female patients with advanced breast cancer (35-61 y.o.). Human fetal adrenals were obtained from three female fetuses at 15 to 20 weeks of gestational age delivered at the time of legal abortion. Fresh bovine adrenals were obtained from a local slaughterhouse.

\section{Lipoproteins}

Human LDL, HDL and lipoprotein poor serum (LPPS) were prepared as described by Havel et al. (1955). The sera obtained from normal men were centrifuged at $10,000 \mathrm{rpm}$ for $30 \mathrm{~min}$ in a Sorvall centrifuge using an SS-34 rotor, and floating chylomicron was removed. The density of the remaining preparation was adjusted to $\mathrm{d}=1.019,1.063$ and $1.215 \mathrm{~g} / \mathrm{ml}$ with $\mathrm{NaCl}$ and $\mathrm{NaBr}$, and fractions of LDL $(1.019<$ $\mathrm{d}<1.063 \mathrm{~g} / \mathrm{ml})$, HDL $(1.063<\mathrm{d}<1.215 \mathrm{~g} / \mathrm{ml})$ and LPPS $(\mathrm{d}>1.215 \mathrm{~g} / \mathrm{ml})$ were separated one after another by differential ultracentrifugation in a Hitachi ultracentrifuge (RP-65) using a 65 rotor at $40,000-50,000 \mathrm{rpm}$ for $18-30 \mathrm{~h}$. Each fraction was dialyzed for $24 \mathrm{~h}$ against $0.15 \mathrm{M} \mathrm{NaCl}$ containing $0.3 \mathrm{mM}$ EDTA (pH 7.0), stored at $4^{\circ} \mathrm{C}$ until use and used within 4 weeks. The cholesterol/protein ratios were $1.6: 1$ and $1: 3.2$ for LDL and HDL fractions, respectively. The purified LDL and HDL fractions were not contaminated with each other, as determined by Ouchterolony immunodiffusion with anti-apolipoprotein A-I and anti-LDL antibody.

Primary monolayer culture of adrenocortical cells

Overt fat was removed aseptically from the adrenals of human adults and fetuses, and the bovine. The cortex and medulla were separated as much as possible. The tissues from the adrenal cortex (whole zones) were placed in sterilized dishes, cut into pieces, and washed several times with modified Eagle's medium (MEM). The pieces were then transferred into MEM containing $0.25 \%$ collagenase and cells were separated by stirring for $60 \mathrm{~min}$ at room temperature. The dispersed cells were washed three times with MEM and placed in a plastic dish (Falcon $3001, \phi 35 \mathrm{~mm}$ ) at a density of $0.5 \times 10^{5}$ cells per dish. The cells were incubated in $1 \mathrm{ml}$ MEM containing 10\% FCS and $50 \mu \mathrm{g}$ streptomycin at $37^{\circ} \mathrm{C}$ under $5 \% \quad \mathrm{CO}_{2}$ in air. Viability after the treatment with collagenase, as determined by the trypan blue dye exclusion method, exceeded $90 \%$. When the suspension was incubated further for another $24 \mathrm{~h}$, the plating efficiency was $50-70 \%$. The medium was changed daily and centrifuged at $1500 \mathrm{rpm}$ for $5 \mathrm{~min}$. The supernate was stored at $-20^{\circ} \mathrm{C}$ until analyzed for steroid hormone. Adrenocortical cells used for each experiment were obtained from one adrenal, and each experiment was run in triplicate. To observe the effects of LDL or HDL on adrenal steroidogenesis, cultured human adult adrenocortical cells were pretreated with LPPS. Adrenocortical cells were cultured in MEM with $10 \%$ FCS on the first day, and then in MEM with 10\% LPPS for 3 consecutive days. These cells were then incubated in the presence of LDL (100 $\mu \mathrm{g}$ of cholesterol $/ \mathrm{ml})$ and $10^{-7} \mathrm{M} \mathrm{ACTH}$ for 5 consecutive days. The cells pretreated with LPPS for 2 days produced a maximum increase in cortisol secretion with the administration of LDL (data not shown).

\section{Assays}

Cortisol was measured with a Cortisol RIA 
kit (Daiichi Radioisotope Laboratory, Tokyo, Japan). Dehydroepiandrosterone sulfate (DHEAS) was extracted with ethyl alcohol and determined by RIA using specific antisera to 11deoxy-17-ketosteroids (Sekihara and Ohsawa, 1974). Aldosterone was extracted with dichloromethane and measured with an Aldoterone RIA kit (CEA-IRE-SORIN, France). Protein and total cholesterol were determined by the method of Lowry et al. (1951) and the procedure of Zurkowski (1964).

\section{Statistical analyses}

The statistical significance of cell culture data was determined by Student's $t$-test. The results are expressed as the mean \pm SD of values from triplicate culture dishes.

\section{Results}

\section{Effects of ACTH concentration}

The effects of ACTH concentration on cortisol secretion in the presence of LDL or HDL are shown in Fig. 1. Human adult adrenocortical cells pretreated with
LPPS for 2 days were cultured in the presence of LDL or HDL with the dose of ACTH ranging from $10^{-9} \mathrm{M}$ to $10^{-6} \mathrm{M}$. The cortisol secretion increased with the concentration of ACTH and its maximum was $10^{-7} \mathrm{M}$ ACTH.

\section{Effects of $L D L$ and $H D L$ concentration}

The effects of LDL or HDL concentration on cortisol secretion in the presence of $10^{-7} \mathrm{M}$ ACTH are shown in Fig. 2. Either LDL or HDL was added at concentrations ranging from 0 to $400 \mu \mathrm{g}$ of cholesterol $/ \mathrm{ml}$ to the cultures of human adult and bovine adrenocortical cells pretreated with LPPS.

Cortisol secretion from these cells increased with the concentration of LDL or $\mathrm{HDL}$, and reached a plateau. The $\mathrm{ED}_{50}$ values for $\mathrm{LDL}$ and $\mathrm{HDL}$ were $12 \mu \mathrm{g} / \mathrm{ml}$ and $70 \mu \mathrm{g} / \mathrm{ml}$ in cells from adults, and 8 $\mu \mathrm{g} / \mathrm{ml}$ and $62 \mu \mathrm{g} / \mathrm{ml}$ in bovine cells, respectively. In both human adult and bovine adrenocortical cells the $\mathrm{ED}_{50}$ value for $\mathrm{LDL}$

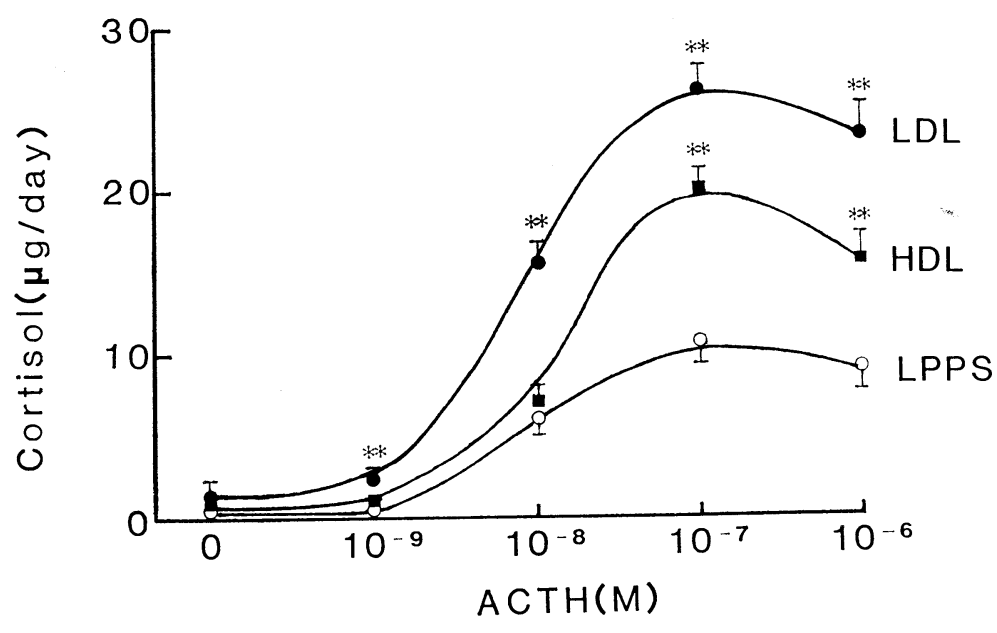

Fig. 1. Effects of ACTH concentration on cortisol secretion from human adult adrenocortical cells in the presence of LDLor HDL-cholesterol.

Human adult adrenocortical cells were maintained $\left(37^{\circ} \mathrm{C}, 5 \% \mathrm{CO}_{2}\right)$ in $\mathrm{MEM}$ containing $10 \%$ FCS for 1 day, pretreated with MEM containing $10 \%$ LPPS for 2 days without ACTH and were then incubated for 5 days in lipoprotein-poor media (LPPS) alone or supplemented with human HDL

(100 $\mu \mathrm{g}$ of cholesterol $/ \mathrm{ml})$ or human LDL $(100 \mu \mathrm{g}$ of cholesterol $/ \mathrm{ml})$ in various ACTH concentration $\left(0-10^{-6} \mathrm{M}\right)$.

Figure shows the secretion of cortisol in day 3 in the presence of varying concentration of ACTH.

The results presented are the mean \pm SD for triplicate dishes.

** $\mathrm{p}<0.01$ vs. LPPS

LPPS alone ( $\bigcirc$ ), LPPS plus HDL (ם), LPPS plus LDL (๑). 
(a) Human adult

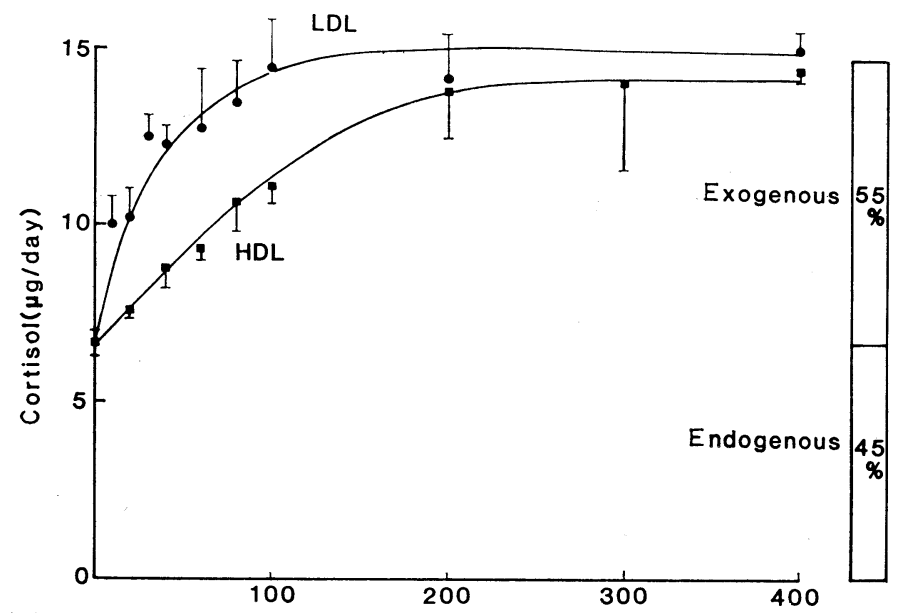

Fig. 2. Effects of human HDL- (ם- $\square)$ and LDL(O- ) cholesterol concentration on ACTHstimulated cortisol secretion by cultured human adult (a) and bovine adrenocortical cells (b).

Human adult adrenal (b) Bovine

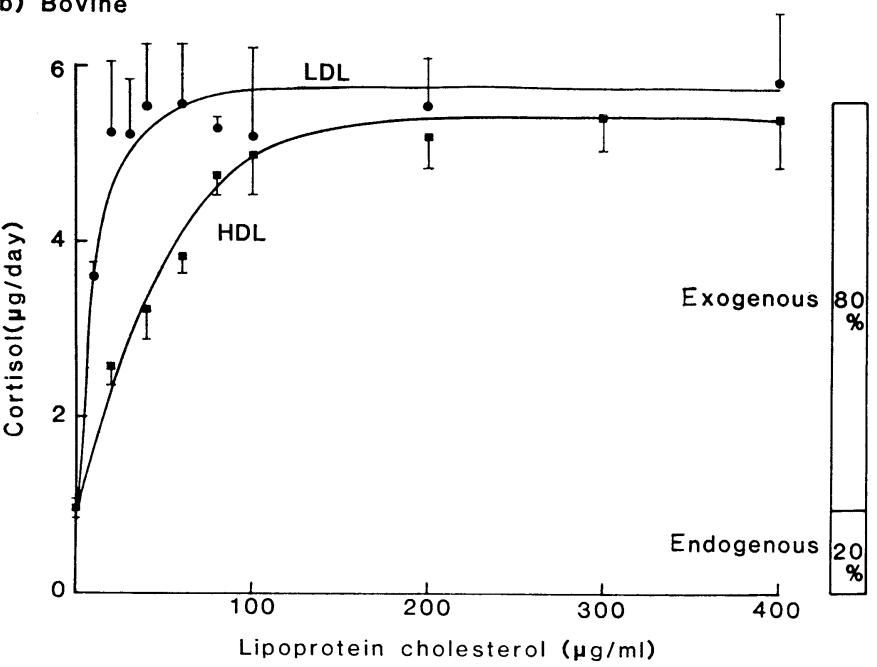
secretion of cortisol in day 3 stimulated by ACTH $\left(10^{-7} \mathrm{M}\right)$ and bovine adrenal secretion rates of cortisol in day 2 stimulated by ACTH $\left(10^{-7} \mathrm{M}\right)$ were demonstrated. The results presented are the mean \pm SD for triplicate dishes.

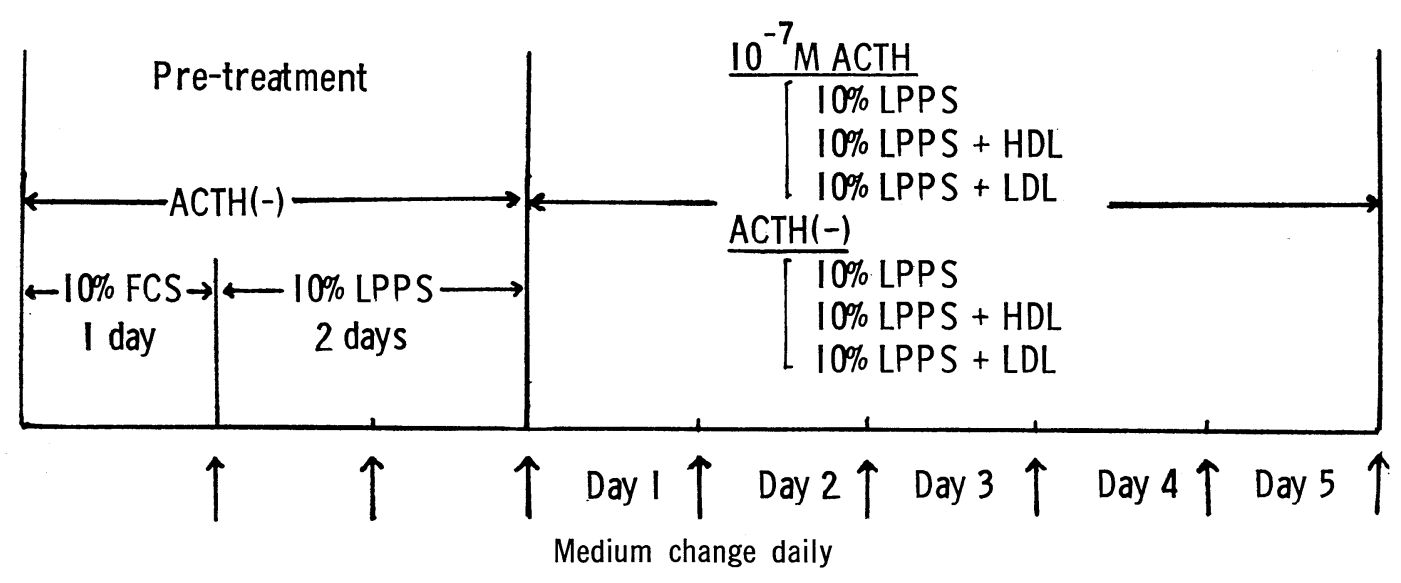

Fig. 3. Protocol of treatment of cells with HDL or LDL. 
was lower than that for HDL. In the human adult cells, the ratio of maximum secretion in the presence of lipoprotein over secretion in the absence of lipoprotein was $15: 7$, indicating that lipoprotein cholesterol contributed to about $55 \%$ of the cortisol formed. In the bovine cells, the ratio was $6: 1$, indicating that about $80 \%$ of the secreted cortisol derived from the lipoprotein cholesterol.

In view of these results, the adrenocortical cells were cultured for 1 day in MEM with $10 \%$ FCS, for 2 days in MEM with $10 \%$ LPPS, then for 5 days in medium containing LPPS, HDL (100 $\mu \mathrm{g}$ of cholesterol/ml) or LDL (100 $\mu \mathrm{g}$ of cholesterol $/ \mathrm{ml})$ in the absence or presence of $10^{-7} \mathrm{M} \mathrm{ACTH}$ (Fig. 3). The medium was changed daily. Cortisol, DHEA-S and aldosterone in the medium were determined and the daily secretions were compared.

Roles of HDL and $L D L$ on the secretion of steroids from human adrenocortical cells

The effects of HDL- or LDL-cholesterol on the secretion of cortisol from cultured human adult adrenocortical cells in the presence of ACTH were determined using 5 adrenals (Table 1). The patterns of cortisol secretion were similar in all the cell cultures from these 5 adrenals. In every adrenal the daily secretion of cortisol was increased in the presence of HDL- or LDLcholesterol, and LDL-cholesterol was utilized more than HDL cholesterol in cortisol production. On the 3rd day, in the presence of IACTH, cortisol secretion was 1.6 and 1.8 times higher in HDL or LDL groups than in the case of LPPS only.

In the adrenals from the youngest woman (35 yr) and the oldest woman (61 yr) among these 5 adrenals, the effects of HDL- or LDL-cholesterol on the secretion of DHEA-S and aldosterone in addition to cortisol were determined in the presence and absence of $10^{-7} \mathrm{M}$ ACTH (Fig. 4, 5). Adrenocortical cells from these adrenals secreted mainly

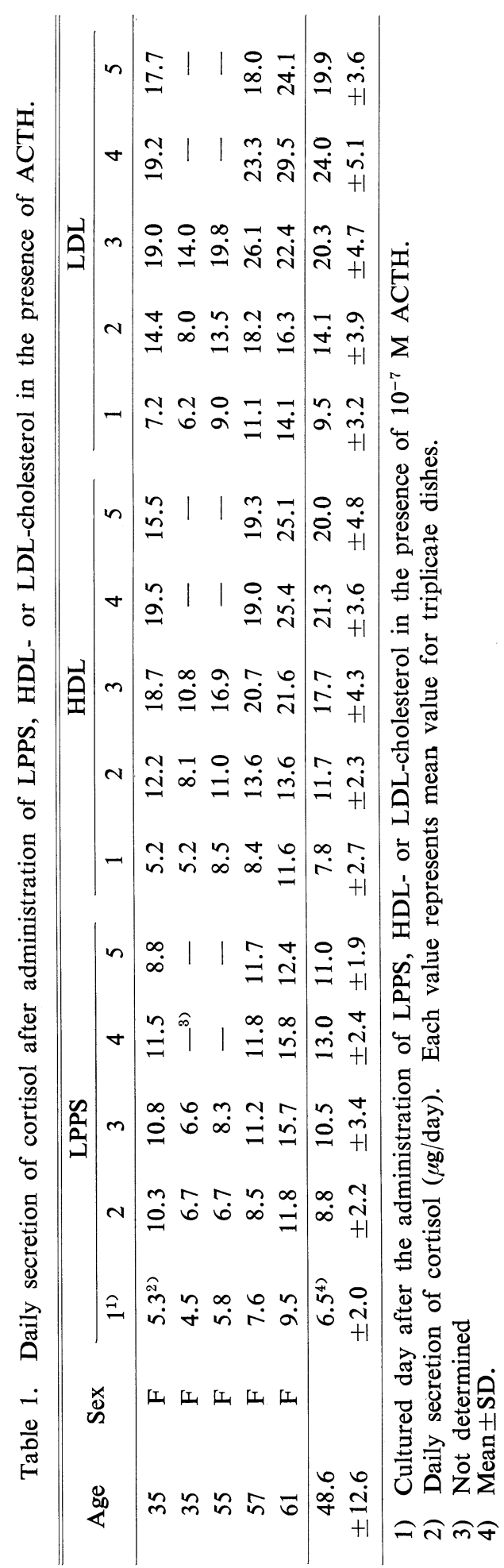




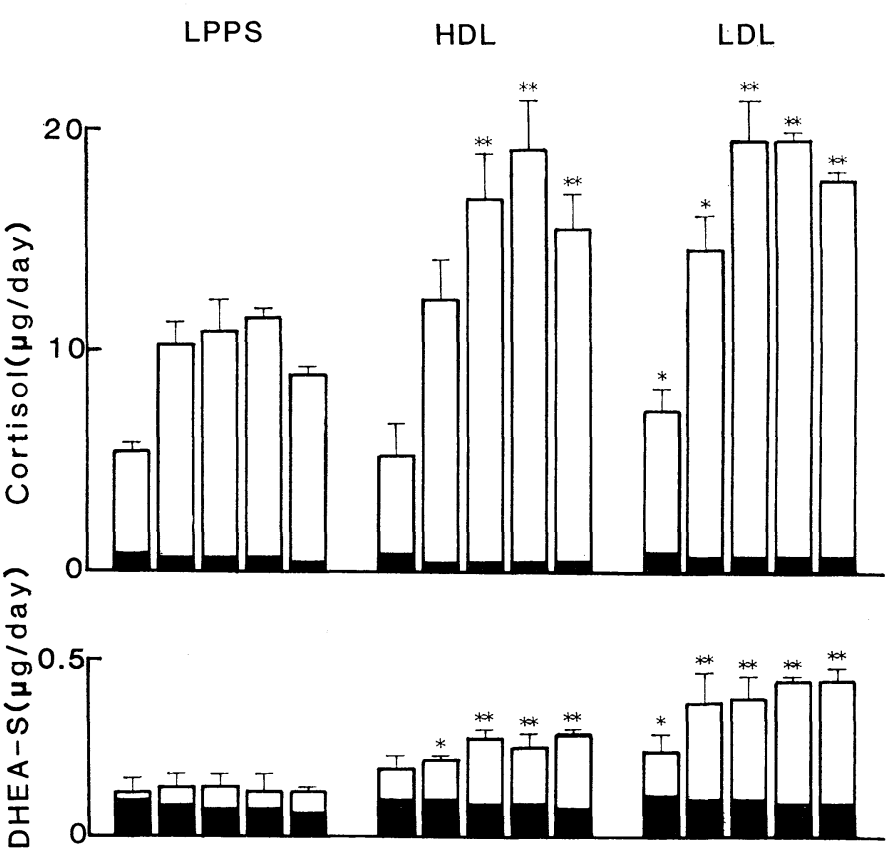

Fig. 4. Effect of HDL- or LDL-cholesterol on human adult adrenal steroidogenesis in the presence and absence of ACTH (Case 35 y.o.).

Human adult adrenocortical cells $\left(0.5 \times 10^{5} \mathrm{cells} / \mathrm{dish}\right)$ were treated using the same protocol as for Fig. 3. The cells were incubated for 5 days in the absence (closed column) and presence (open column) of ACTH $\left(10^{-7} \mathrm{M}\right)$ in LPPS alone or in the presence of human HDL (100 $\mu \mathrm{g}$ of cholesterol $/ \mathrm{ml}$ ) or human LDL $(100 \mu \mathrm{g}$ of cholesterol/ $\mathrm{ml}$ ). The results presented are the mean \pm SD for triplicate dishes.

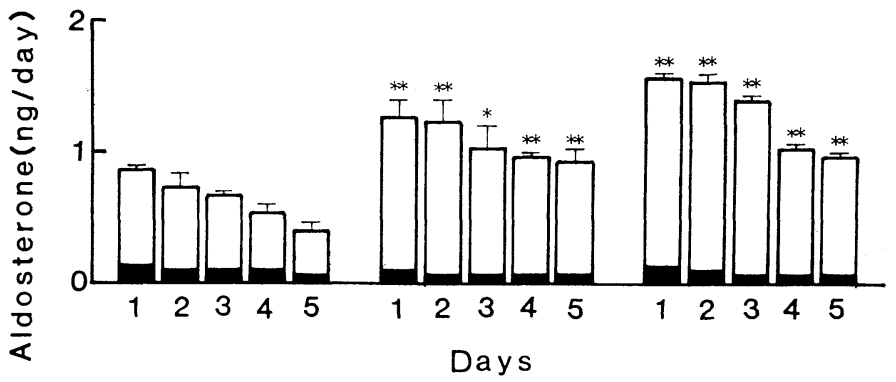

${ }^{*} \mathrm{p}<0.05,{ }^{* *} \mathrm{p}<0.01$ vs. LPPS

cortisol. In the absence of ACTH, the daily secretion of cortisol, DHEA-S and aldosterone decreased with time, but in the presence of ACTH, the secretion of each steroid markedly increased. The secretions of cortisol and DHEA-S continued to increase during the 5-day culture period, whereas there was an increase in aldosterone secretion in response to ACTH, but a gradual decline thereafter. Neither HDL nor LDL increased the secretion of cortisol, DHEA-S or aldoserone in the absence of ACTH, but did significantly increase the secretions in the presence of ACTH. There was no significant difference in DHEA-S secretion from the adrenocortical cells of the 35 y.o. (Fig. 4) and 61 y.o. subjects (Fig. 5).

The effect of LDL- or HDL-cholesterol on human fetal adrenal steroidogenesis was also determined (Fig. 6) and compared to the findings with human adult adrenal steroidogenesis. Human fetal adrenocortical cells secreted mainly DHEA-S. In the absence of ACTH, the secretion of cortisol, DHEA-S and aldosterone decreased with the day of incubation. In the presence of ACTH, all secretions were markedly increased and continued to increase during the 5-day cultured period. The addition of either HDL 
LPPS
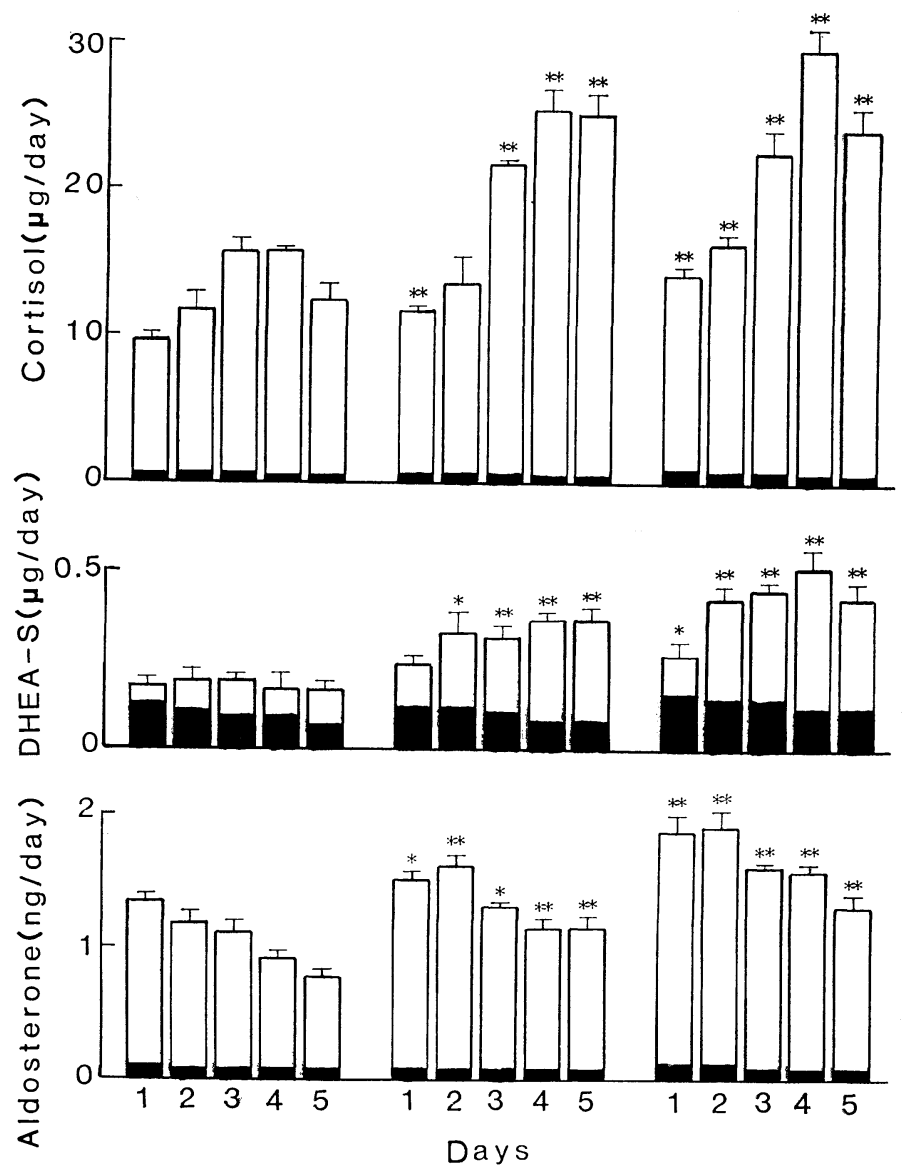

Fig. 5. Effect of HDL- or LDL-cholestesterol on human adult adrenal steroidogenesis in the presence and absence of ACTH (Case 61 y.o.).

The treatment of cells is the same as for Fig. 4. or LDL caused a significant increase in the secretion of cortisol, DHEA-S and aldosterone both in the absence and presence of ACTH. In the presence of ACTH, the addition of HDL and LDL increased the daily secretion of DHEA-S 1.5 and 1.8 times, respectively, on the 3rd day, compared with that in the medium to which only LPPS was added.

\section{Discussion}

It has been reported that the principal source of exogenous cholesterol utilized in adrenocortical steroidogenesis is HDL in rats, but LDL in mice, bovine and human fetuses (Gwynne and Strauss III, 1982). However, there is no report about steroidogenesis in human adult adrenals. We found that either LDL or HDL in the presence of ACTH increased secretion of various steroid hormones from human adult and fetal adrenocortical cells in culture. The utilization of LDL-cholesterol was higher than that of HDL-cholesterol. According to Brown and Goldstein et al. (1979), the LDL pathway involving LDL receptors may play an important role in the incorporation of $\mathrm{LDL}$ into adrenocortical cells of mice, bovine, 
LPPS HDL

LDL

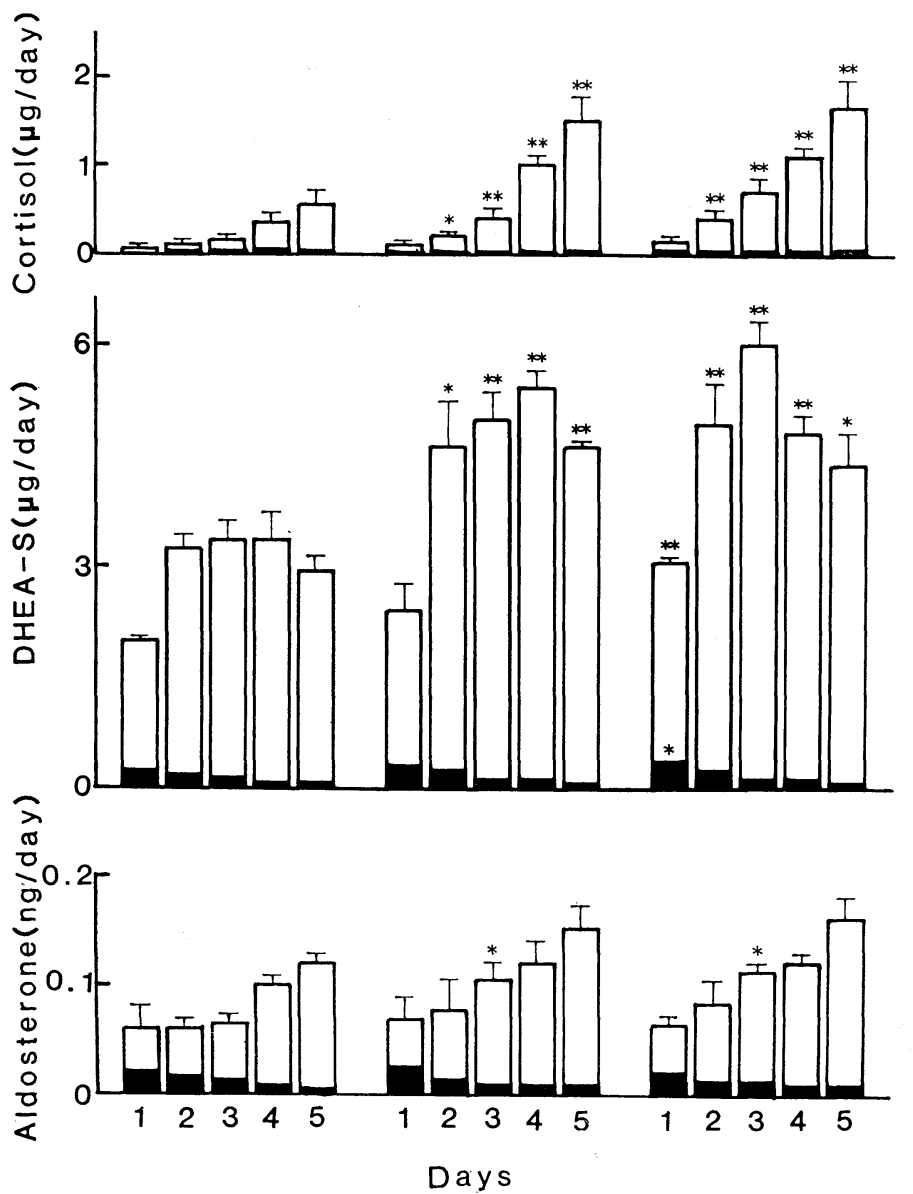

Fig. 6. Effect of HDL- or LDL-cholesterol on human fetal adrenal steroidogenesis in the presence and absence of ACTH (15 weeks gestation).

The treatment of cells in the same as for Fig. 4. and human fetal adrenal (Carr et al. 1980b). Kovanen et al. (1979b) and Ohashi et al. (1981) reported that the $\mathrm{Kd}$ values for binding of ${ }^{125}$ I-LDL to adrenals of bovine and human fetuses were about 12-20 $\mu \mathrm{g}$ of protein $/ \mathrm{ml}$. The present study on human adult and bovine adrenocortical cells showed that the secretion of cortisol increased with the concentration of LDL and was saturable (Fig. 2). The $E_{50}$ values for the secretion were about $10 \mu \mathrm{g}$ of cholesterol $/ \mathrm{ml}$. These results suggest that human adult adrenocortical cells utilize LDL through LDL receptors similarly to bovine adrenocortical cells. It was noted, however, that bovine adrenals differed from human adult adrenals with regard to the extent of involvement of exogenous cholesterol in the production of cortisol. In bovine adrenals, exogenous cholesterol accounted for about $80 \%$ of all the cholesterol used, but in human adults the rate was about 55\%. Borkowski et al. (1967) reported that about $80 \%$ of cholesterol used in the steroid production of adult adrenals in vivo was derived from exogenous plasma cholesterol. Carr and Simpson (1981) reported that the rate was about $70 \%$ in vitro in human fetuses. In our present experiments, the rate for bovine approximated these values, but that for human adults was lower, thereby indicating that endogenous cholesterol was involved in steroid produc- 
tion at a high rate in human adult adrenals. This high rate possibly reflects the fact that the concentration of cholesterol in the human adrenal is higher than that in the bovine (Khan et al., 1963; Cargill and Cook, 1964).

The addition of HDL to the cultured cells in the presence of ACTH also increased steroid hormone secretion from human adult and fetal adrenocortical cells. The binding of HDL to the specific receptors was demonstrated, but unlike LDL receptors, the internalization and degradation of HDL were not observed by Gwynne and Hess (1980) in rat adrenal cells, or by Kovanen et al. (1979c) in cells of adrenal tumors of the mouse. Carr et al. (1980b) mentioned the possible involvement of lipase liberated from the cytoplasmic membrane following treatment with heparin, in the uptake of HDL-cholesterol into the adrenal. We labeled free cholesteol in HDL and LDL with ${ }^{3} \mathrm{H}$ by the method of Gwynne et al. (1976) and compared the incorporation into the adrenocortical tissues of human adults. In the human adult adrenals, as in the rat adrenals, about 3 times as much HDLcholesterol as LDL-cholesterol was incorporated, suggesting that this incorporation of free cholesterol may play a role in the supply of cholesterol to the adrenocortical cells (Higashijima et al., 1979). As shown in Fig. 1, however, the addition of HDL increased the secretion of cortisol from human adult adrenal cells in the presence of a relatively high concentration of $\mathrm{ACTH}$, but there was no increase when the concentration was low. Therefore, the incorporation and utilization of HDL-cholesterol may occur only when the intracellular production of steroids is markedly stimulated. As shown in Fig. 2, human adrenocortical cells synthesized cortisol using more LDL than HDL. The plasma concentration of LDL-cholesterol is 2 to 3 times higher than that of HDL-cholesterol in adults (Osborne and Brewer, 1977). These findings suggest that, in vivo, the exogenous cholesterol used in the biosynthesis of steroids is mainly from LDL-cholesterol, but the proportion of cholesterol synthesized de novo is fairly large in human adrenals.

Significant differences between patterns of steroid secretion in human fetal and adult adrenals were observed. The fetal adrenal secreted mainly DHEA-S at a level about 10 times that of the adult adrenal. On the other hand the adult adrenal secreted mainly cortisol at a level about 20 times that of the fetal adrenal. These results support the theory that the inner fetal zone which constitutes about $80 \%$ of the fetal adrenal cortex produced mainly DHEA-S because of weaker activity of $3 \beta$-hydroxysteroid dehydrogenase (Simpson and Gill, 1981).

The secretion of aldosterone from the normal adrenal showed a gradual decrease with the time of culture when ACTH was administered chronically in vitro (Müller, 1978; Aguilera et al., 1981). The possible mechanism of this decrease is as follows. (1) Aldosterone synthesis is inhibited in the "late pathway" by corticosterone and 18OH-deoxycorticosterone (Müller, 1978) or oxidants (Crivello et al., 1982). (2) The number of angiotensin II receptors is decreased (Aguilera et al., 1981). And (3) zona glomerulosa cells are transformed to zona fasciculata cells (Hornsby et al., 1979; Vazir et al., 1981). On the other hand, in human fetal adrenal cells the secretion of aldosterone increased with time, when they were stimulated with ACTH. In these cells, aldosterone and cortisol were secreted to some extent. Therefore, the production of corticosterone and 18-OH-dehydrocorticosterone in these cells to be insufficient to inhibit the "late pathyway" of the biosynthesis of aldosterone, otherwise these immature cells seem to be highly capable of handling oxidants. 


\section{Acknowledgements}

We thank Dr. Yasuo Nomura, Chief of The Department of Surgery, National Kyushu Cancer Center, and the staff of the Department of Urology, Kyushu University (Professor Joichi Kumazawa) for providing the human adrenal glands.

This work was supported in part by grants Nos. 5644080 and 5748042 from the Ministry of Education, Science and Culture, and from the Ministry of Health and Welfare for research on Intractable Diseases "Disorders of steroid hormones" (Chairman: Prof. Hiroshi Ibayashi), Japan.

These data were presented in part at the 55th and 56th Annual Meetings of the Japan Endocrine Society.

\section{References}

Aguilera, G., K. Fujita and K. J. Catt (1981). Mechanisms of inhibition of aldosterone secretion by adrenocorticotropin. Endocrinology 108, 522-528.

Andersen, J. M. and J. D. Dietschy (1978). Relative importance of high and low density lipoproteins in the regulation of cholesterol synthesis in the adrenal gland, ovary and testis of the rat. J. Biol. Chem. 255, 90249032.

Borkowski, A. J., S. Levin, C. Delcroix, A. Mahler and V. Verhas (1967). Blood cholesterol and hydrocortisone production in man: Quantitative aspects of the utilization of circulating cholesterol by the adrenals at rest and under adrenocorticotropin stimulation. $J$. Clin. Invest. 46, 797-811.

Brown, M. S., P. T. Kovanen and J. L. Goldstein (1979). Receptor-mediated uptake of lipoprotein-cholesterol and its utilization for steroid synthesis in the adrenal cortex. Recent Prog. Horm. Res. 35, 215-257.

Cargill, D. I. and R. P. Cook (1964). The free and esterified sterol present in bovine adrenal cortex and medulla. Biochem. J. 93, 504-512.

Carr, B. R., C. R. Parker Jr., L. Milewish, J. C. Porter, P. C. MacDonald and E. R. Simpson (1980a). The role of low density, high density and very low density lioproteins in steroidogenesis by the human fetal adrenal gland. Endocrinology 106, 1854-1860.
Carr, B. R., J. C. Porter, P. C. MacDonald and E. R. Simpson (1980b). Metabolism of low density lipoprotein by human fetal adrenal tissue. Endocrinology 107, 1034-1040.

Carr, B. R., E. R. Simpson (1981). De novo synthesis of cholesterol by human fetal adrenal gland. Endocrinology 108, 2154-2162.

Crivello, J. F., P. J. Hornsby and G. N. Gill (1982). Metyrapone and antioxidants are required to maintain aldosterone synthesis by cultured bovine adrenocortical zona glomerulosa cells. Endocrinology 111, 469-479.

Dexter, R. N., L. M. Fishman and R. L. Ney (1970). Stimulation of adrenal cholesterol uptake from plasma by adrenocorticotropin. Endocrinology 87, 836-846.

Faust, J. R., J. L. Goldstein and M. S. Brown (1977). Receptor-mediated uptake of low density lipoproteins and utilization of its cholesterol for steroid synthesis in cultured mouse adrenal cells. J. Biol. Chem. 252, 4861-4871.

Gwynne, J. T., D. Mahafee, H. B. Brewer jr. and R. L. Ney (1976). Adrenal cholesterol uptake from plasma lipoproteins: Regulation by corticotropin. Proc. Natl. Acad. Sci. USA 73, 4329-4333.

Gwynne, J. T. and B. Hess (1980). The role of high density lipoproteins in rat adrenal choleserol metabolism and steroidogenesis. $J$. Biol. Chem. 255, 10875-10883.

Gwynne, J. T. and J. F. Strauss III (1982). The role of lipoproteins in steroidogenesis and cholesterol metabolism in steroidogenic glands. Endocrine Rev. 3, 299-329.

Havel, R. J., H. A. Eder and J. H. Bragdon (1955). The distribution and chemical composition of ultracentrifugally separated lipoproteins in human serum. J. Clin. Invest. 34, 1345-1353.

Higashijima, M., M. Ohashi, K. Kato and H. Ibayashi (1979). Adrenal cholesterol uptake of high and low density lipoproteins. (Abstract) Folia Endocrinol. Japon. 55, 355. (in Japanese).

Hornsby, P. J., M. J. O'Hare and A. M. Neville (1979). Function and morphological observation on rat adrenal zona glomerulosa cells in monolayer culture. Endocrinology 95, 12401251.

Jansen, H. and W. C. Hulsmann (1980). Heparinreleasable (liver) lipase(s) may play a role in the uptake of choleserol by steroid-secreting tissues. Trends Biochem. Sci. 5, 265-268.

Khan, B., G. E. Cox and K. Asdel (1963). 
Cholesterol in human tissues. Arch. path. 76, 369-381.

Kovanen, P. T., J. R. Faust, M. S. Brown and J. L. Goldstein (1979a). Low density lipoprotein receptors in bovine adrenal cortex. I. : Receptor-mediated uptake of low density lipoprotein and utilization of its cholesterol for steroid synthesis in cultured adrenocortical cells. Endocrinology 104, 599-609.

Kovanen, P. T., S. K. Basu, J. L. Goldstein and M. S. Brown (1979b). Low density lipoprotein receptors in bovine adrenal cortex. II.: Low density lipoprotein binding to membranes prepared from fresh tissue. Endocrinology 104, 610-616.

Kovanen, P. T., W. J. Schneider, G. M. Hillman, J. L. Goldstein and M. S. Brown (1979c). Separate mechanisms for the uptake of high and low density lipoproteins by mouse adrenal gland in vivo. J. Biol. Chem. 254, 5498-5505.

Kovanen, P. T., J. L. Goldstein, D. A. Chappel and M. S. Brown (1980). Regulation of low density lipoprotein receptors by adrenocorticotropin in the adrenal gland of mice and rats in vivo. J. Biol. Chem. 25, 5591-5598.

Lowry, O. H., D. J. Rosebrough, A. L. Farr and R. J. Randall (1951). Protein measurement with the folin phenol reagent. J. Biol. Chem. 193, 265-275.

Müller, J. (1978). Suppression of aldosterone biosynthesis by treatment of rats with adreno- corticotropin comparison with glucocorticoid effects. Endocrinology 103, 2061-2068.

Ohashi, M., B. R. Carr and E. R. Simpson (1981). Effects of adrenocorticotropic hormone on low density lipoprotein receptors of human fetal adrenal tissue. Endocrinology 108, 12371342.

Osborne, Jr. J. C. and H. B. Brewer Jr. (1977). The plasma lipoproteins. Adv. Protein Chem. 31, 253-337.

Sekihara, H. and N. Ohsawa (1974). A radioimmunoassay for serum 11-deoxy-17-ketosteroids. Steroids 23, 245-258.

Simpson, M. H. and G. N. Gill (1981). Regulation of the fetal human adrenal cortex: Effects of adrenocorticotropin on growth and function of monolayer cultures of fetal and definitive zone cells. Endocrinology 108, 1879-1779.

Srere, P. A., I. L. Chaikoff and W. G. Dauben (1948). The in vitro synthesis of cholesterol from acetate by surviving adrenal cortical tissue. J. Biol Chem. 176, 829-833.

Vazir, H., B. J. Whitehouse, G. P. Vinson and E. McCredie (1918). Effects of prolonged ACTH treatment on adrenal steroidogenesis and blood pressure in rats. Acta Endocrinol. (kbh) 93, 533-542.

Zurkowski, P. (1964). A rapid method for cholesterol determination with a single agent. Clin. Chem. 10, 451-453. 